\title{
Par Lietuvu latviski: sabiedriskās dzīves reāliju nosaukumi
}

\section{About Lithuania in Latvian: the names of public life realias}

\author{
Regīna Kvašìte \\ Šiauliu universitetas \\ P. Višinskio g. 38, Siauliai LT-76352, Lietuva \\ E-pasts:kvasyte@hu.su.lt
}

Par Lietuvas ekonomisko, politisko, sociālo un kultūras dzīvi latviešu valodā raksta, lietojot tekstos dažādus reāliju nosaukumus. Pētījuma mērḳis - izanalizēt Lietuvas kultūrvidei raksturīgo sabiedriskās dzīves reāliju nosaukumus (rakstā sauktus par bezekvivalenta leksiku, reizēm - par kultūraizguvumiem) latviešu valodā. Lai noskaidrotu atveides likumsakarības, sastatījumam izmantotas gan tulkojošās, gan pašvalodas vārdnīcas. Publikācijās par Lietuvu un tās tautas vēsturi, pārsvarā enciklopēdijās, arī populārzinātniskajos, informatīvajos un preses izdevumos, visbiežāk sastopami dažādu laikposmu vēsturisko un aktualizēto reāliju nosaukumi. Pēc semantikas šos nosaukumus var iedalīt vairākās grupās: 1) valsts simboli valsts nosaukums un pamatdokuments, gerbonis, institūcijas, apbalvojumi, 2) personas pēc to statusa, pienākumiem vai nodarbošanās, 3) administratīvi teritoriālās vienības un to pārvaldības iestādes, 4) naudas vien̄̄bas, 5) partijas un sabiedriskās kustības. Nosaukumu atveide latviešu valodā atkarīga no avota, kurā šīs leksikas vienības fiksētas, kā arī no autoru skatījuma uz bezekvivalenta leksikas lietošanu. Pārsvarā minētie lietuviešu nosaukumi tiek latviskoti, kaut gan reizēm tekstā konstatēti arī paskaidrojumi. Savāktā materiāla analīze liecina, ka praksē vērojama liela, ne vienmēr pārdomāta sabiedriskās dzīves reāliju nosaukumu atveides dažādība. Īpaša uzmanība ir jāpievērš reāliju nosaukumu, kas veic vēstures terminu funkcijas, lietošanai. Lai komunikācija mērksvalodā būtu veiksmīga, ir jānovērtē, cik labi adresāts pazīst Lietuvu, zina Lietuvas kultūrvides reālijas vai prot avotvalodu u. tml.

Atslēgvārdi: latviešu valoda; lietuviešu valoda; bezekvivalenta leksika; sabiedriskās dzīves reāliju nosaukumi; avotvaloda; mērķvaloda.

\section{levads}

Valsts tēla veidošana un tā popularizēšana, uzmanības piesaistīšana un vēlēšanās būt atpazīstamiem pasaulē ir jebkuras valsts mērķis. Lai iepazītu valsti un/vai tautu, izprastu tās kultūru un novērtētu specifiku, uzmanību saista ekonomiskās, politiskās, sociālās un kultūras dzīves reālijas. „Cilvēku veidota un kopta sabiedriskā telpa, kurā noteikta sabiedrība vēsturiski attīstījusi savu saimniecisko darbību un kultūru, radījusi materiālās un garīgās vērtības, piekopusi noteiktu dzīvesveidu, veidojusi uzvedības, attiecību un saskarsmes normas. Vide, kas rosina kultūras vērtību, normu un dzīvesziņas apguvi ..” (Skujiņa 2011, 49) jeb kultūrvide ir jāņem vērā, nodrošinot veiksmīgu komunikāciju un izvēloties piemērotus valodas izteiksmes līdzekḷus. Radniecīgo lietuviešu un latviešu tautu valsts un sabiedrības dzīves struktūrā, valsts simbolikā un sabiedriski vēsturiskajās 
reālijās var atrast priekšstatus, parādības, priekšmetus u. tml., kas raksturīgi tikai vienai no tām, savukārt otra šīs reālijas nepazīst. Tāpēc ir svarīgi domāt par to nosaukumu lietošanu (atveidi) otrajā baltu valodā. Publikācijās par Lietuvu latviešu valodā sastopami dažādi sabiedriskās dzīves reāliju nosaukumi. Pētījuma mērķis izanalizēt Lietuvas sabiedriskās dzīves reāliju nosaukumus un to lietošanu latviešu valodā. Izmantojot semantiskās analīzes, sastatījuma un aprakstošo metodi, izanalizēti vārdnīcu un enciklopēdiju dati, kā arī dažādi oriǵinālvalodā rakstītie vai no latviešu valodas tulkotie populārzinātnisko un preses izdevumu teksti (sk. saīsinājumu un avotu sarakstu).

\section{Reālijas, to nosaukumi un semantika}

Lai vispārināti apzīmētu pētījumam izvēlēto reāliju nosaukumus, lingvokulturologijas, etnolingvistikas un saskarnozaru teorijā joprojām nav vienota viedokḷa. Latviešu valodniecības terminu vārdnīcā reālija definēta samērā vispārīgi: ,[Ī] tenības priekšmets, parādība, dzīva būtne, abstrakts jēdziens, ko nosauc valodas vienība" (Skujiṇa 2007, 321), savukārt lietuviešu valodā (tās tulkošanas teorijā) uzsvērts šo vienību kultūrspecifiskais raksturs: „,[V]ārdi vai vārdkopas, kas apzīmē noteiktus jēdzienus, priekšmetus, parādības, kuras raksturīgas tautas, valsts, cilts geogrāfiskajai videi, kultūrai, sadzīvei un atspoguḷo tautisko, vietējo vai vēsturisko kolorītu. Reālijas (precizitātes labad vēl sauktas par reāliju nosaukumiem) var atveidot kalkējot, aizgūstot, aprakstoši tulkojot un citos līdzịgos veidos .." (Pažūsis et al. [b. g.], 90) ${ }^{1}$. Saikni ar kultūrvidi atspoguḷo ar̄̄ Kazimiera Ambrasa-Sasnavas (Kazimieras Ambrasas-Sasnava 1978, 135) sniegtā definīcija: „oriǵināla valodā sastopamais vārds vai vārdkopa, kas nosauc sadzīves, vēstures, kultūras vai citu sabiedriskās dzīves jomu tādus priekšmetus, parādības, faktus vai notikumus, kādu tulkojuma valodā parasti nemēdz būt vai tos sauc citādi”. Lietuviešu definīcijā lietots termins originalo kalba (sal. angḷu source language), lai gan mūsdienās latviešu valodā blakus atbilstošajam terminam oriǵināla valoda lieto terminu avotvaloda. Līdzīgi arī citu šīs definīcijas terminu - vertimo kalba (sal. angḷu target language) resp. tulkojuma valoda - mūsdienu terminologijā biežāk sauc par mērkvalodu.

Pētījuma kontekstā svarīgākais ir tieši tas, ka šīs vienības raksturīgas konkrētai kultūrvidei un to nosaukumu lietošana (tulkošana vai atveidošana) var radīt grūtības resp. tiem nav leksisko ekvivalentu mērksvalodā. Šādus vārdus vai vārdu savienojumus gan latviešu, gan lietuviešu valodnieki nereti sauc par bezekvivalenta leksiku. Lietuviešu valodā līdzās terminam beekvivalente leksika (,Vienas valodas leksiskās vienības, kurām nav atbilsmes citas valodas leksikā. Bezekvivalenta leksikai parasti pieskaita citas valodas runātājiem nezināmus (vai maz zināmus) īpašvārdus (personvārdus un vietvārdus), tā sauktās reālijas (jeb reāliju nosaukumus) un leksiskos robus (liet. leksiné spraga)" (Pažūsis et al. [b. g.], 27)) lieto arī ar priedēkli ne- un izskaņu -ine darināto terminu neekvivalentiné leksika (Ambrasas-Sasnava 1978, 132). Š̉ajā sakarā būtu jāmin samērā jaunais latviešu termins lingvokulturēma, „[V]alodas vienība (vārds, vārdu savienojums, teikums,

1 Visus citātus no lietuviešu avotiem - gan teorētiskās literatūras, gan vārdnīcām - tulkojusi raksta autore. Tie citēti avotvalodā, ja ir bijis nepieciešams pievērst uzman̄̄bu lietuviešu tekstam. 
teksts), kurā ietverta verbāla un kultūras informācija, kas l̦auj uztvert un izprast tautas vērtību sistēmu, tautas domāšanas, psihologijas, pasaules izzināšanas pieredzi" (Skujiņa 2011, 53). Uz daļu no vārdiem, ar kuriem apzīmē garīgās un materiālās kultūras reālijas, varētu attiecināt terminu kultūraizguvums. Tā definīcija „[A]votteksta vārds, izteiciens, frazeoloǵisms, kas, nerodot piemērotu mērķteksta ekvivalentu, tiek burtiski pārcelts .. mērķtekstā .." (Skujiņa 2007, 198) l̦auj to lietot samērā plaši, taču pareizāk šķiet šo terminu attiecināt tikai uz patiešām aizgūtiem vārdiem, nevis okazionālu (individuālu vai situatīvu) viena vai otra reālijas nosaukuma lietojumu (plašāk par tautas kultūrvidei raksturīgo reāliju nosaukumu terminoloǵiju sk. Kvašīte 2005; Kvašytė 2009; Kvašytė 2012).

Konkrētas valsts kultūrvidei raksturīgo leksiku var iedalīt 1) tautas jeb etnogrāfisko reāliju nosaukumos un 2) valsts jeb sabiedriskās dzīves reāliju nosaukumos. Lietuviešu etnolingvists Aloīzs Gudavičs (Aloyzas Gudavičius 2009, 93-94) izšksir šādas reāliju nosaukumu lietošanas jomas: nacionālā virtuve, apǵērbi, mūzikas instrumenti, tautasdejas, tradīcijas un paražas, folklora un mitoloǵija, tautas vēstures lietas, kā arī tautas dzīvesvidi - ǵeogrāfiskos objektus, dzīvniekus un augus, klimatiskās dabas parādības. Tieši tautas vēstures lietas, precīzāk, daļa no tām - sabiedriski politiskās dzīves reālijas -, tiek minētas kā vienas no svarīgākajām.

Rakstos par Lietuvu latviešu valodā sastopamas divas sabiedriskās dz̄ives reāliju nosaukumu apakšgrupas:

1) vēsturiskā leksika (historismi²);

2) aktualizētā resp. mūsdienās aktīvajā vārdu krājumā sabiedrība attīstības gaitā notikušo pārmaiņu dēl atgriezusies leksika ${ }^{3}$.

Savukārt pēc semantikas šo reāliju nosaukumi ir:

1) personas pēc statusa, pienākumiem vai nodarbošanās (kunigaikštis, didysis kunigaikštis, knygnešys, šaulys, stribas, seniūnas, seniūnaitis, sajūdininkas);

2) valsts simbolika - valsts nosaukums, apbalvojumi, dokumenti un institūcijas (Lietuvos Didžioji kunigaikštystè, Vytis, Vyčio kryžius, Lietuvos Didžiojo kunigaikščio Gedimino ordinas, seimas, Lietuvos Statutas);

3) naudas vienības (auksinas, litas, centas);

4) administratīvi teritoriālās vienības un to pārvaldības iestādes (apylinkè, seniūnija, seniūnaitija);

5) partijas un sabiedriskās kustības (tautininkai, liaudininkai, Sajūdis).

Šādas semantiskās grupas ir gan vēsturisko, gan mūsdienās lietojamo bezekvivalenta vārdu grupā. Piederība pie vēsturiskās vai aktualizētās leksikas jūtami neietekmē atveides paņēmienu izvēli. Ja arī vērojamas kādas atšķirības, tās saistītas galvenokārt ar to, ka aktualizēto leksiku lieto biežāk un dažādos tekstos,

2 Historisms - 'vēsturiski ierobežota lietojuma vārds, kas nosauc mūsdienās neaktuālu vai zudušu reāliju un kam nav sinonīma mūsdienu valodā' (Skujiņa 2007, 145).

3 Sal. 20. gs. beigu krievu valodas skaidrojošajā vārdnīcā aktualizācijas procesu atspoguḷo attiecīgas norādes par leksikas aktivitāti vai pasivitāti - līdzās norādēm aiziešana pasīva ā un atgriešanās aktīvā izmanto arī norādi aktualizācija (Skljarevskaja 2000, 32), turpat procesa nozīmē lietots termins aktualizācija. 
tāpēc tās atveide ir stabilāka un mazāk variē. N̦emot vērā, ka sabiedriskās dzīves reāliju (personu, organizāciju, sabiedrisko un politisko kustību u. tml.) nosaukumi visbiežāk tiek lietoti kā vēstures termini, jāpievērš uzmanība ne vien to korektai lietošanai avotvalodā, bet arī atveidošanai mērķvalodā. Īpaši svarīgi korekti lietot (atveidot) šos reāliju nosaukumus Lietuvas vēstures, politikas, kultūrvēstures u. tml. tekstos, lai adresātam būtu saprotams teksts, bet netiktu zaudēta kultūrspecifika.

\section{Vēsturisko reāliju nosaukumi}

Lietuvas vēstures, politikas, kultūrvēstures u. tml. kontekstā nozīmīga loma ir senās Lietuvas valsts reālijām, kas veido lietuviešu vēsturisko reāliju kopu, turklāt daḷa no tām ir semantiski saistîtas. Viens no latviešu tekstos visdažādāk atveidotajiem nosaukumiem ir personas nosaukums kunigaikštis - '1. vēst. karavadonis un apgabala valdnieks senajā Lietuvā un citās zemēs; 2. augsts mantojams vai par sasniegumiem piešķirams bajāru tituls; persona, kam pieder šis tituls' (Keinys 2012, 342). Lietuviešu-latviešu vārdnīcā tā ekvivalenti ir četri vārdi - kunigaitis, knazs, kunigs, firsts (Balkevičs et al. 1995, 250), taču analizētajos latviešu tekstos konstatēti pirmie divi"

(1) Krīvu vecākais Lizdeika ņēmies to izskaidrot šādi: $k$ u n i g a i t i m šajā vietā jācel pils, tā būšot tik stipra kā dzelzs, un tās slava izplatīsies tālu un tuvu AKL 5; (2) Bīskaps [Motiejs Valančus] jau tika dēvēts par Ž e m a i t i ja s ku niga iti LV 121; (3) Visinteresantākais no tiem [rituālu aprakstiem] sniegts Dubnicas hronikā, par miera līguma slēgšanu (1351) starp L $i$ e t u vas ku n iga i t $i$ Ķēstuti un Ungārijas karali Ludviku MitE 1994, 241; (4) Lietuvas kunigaitis Gedimins (sk. tālāk didysis kunigaikštis - dižkunigaitis Ģedimins) kādā 1323. gada vēstulē, lūgdams viņam atsūtīt spredikotājus, norāda, ka tiem ir jāprot viena no trim valodāmlietuviešu, poļu vai zemgalı MB 91; (5) 9-12. gs. visā Lietuvas terit[orijā] ${ }^{5}$ izplatījās tīrumu zemk[opība], atdalījās amatn[iecība] un tirdzn[iecība], izveidojās feod[ālas] attiecības; radās pirmie valstiskie veidojumi (zemes) Deltuva, Karšuva, Lietuva u. c., kuru priekšgalā bija k u n i g a iš i (kņ a z i) LPE 157 (sal. tālāk galvenokārt lietots tikai knazi - (6) 13. gs. 30.-60. gados Mindaugs pakl̦āva citu kn a z u zemes LPE 157).

Vēstures grāmatas, enciklopēdijas, informatīva, tūristiem adresēta izdevuma tekstu autori visbiežāk izvēlas pirmo tulkojošajā vārdn̄icā minēto leksēmu kunigaitis (arī vārdkopās Žemaitijas kunigaitis [2], Lietuvas kunigaitis [3; 4]). Tā iekḷauta arī latviešu valodas vārdnīcā, tāpēc ir pamats šo lietuviešu tautas vēsturiskās reālijas nosaukumu uzskatīt par kultūraizguvumu: 'vēst. karavadonis, apgabala, novada valdnieks (feodālajā Lietuvā)’ (Ceplītis, Stengrevica 1980, 490). Retāk latviešu tekstos vienlaikus kā sinonīmi izmantoti abi - kunigaitis un knazs [5] vai tikai

4 Visi vienas reālijas nosaukuma lietošanas piemēri sakārtoti vienā rindkopā un sanumurēti (atsevišķi katras tematiskās grupas ietvaros). Analizējot konkrēto atveides gadījumu, piemēra numurs norādīts kvadrātiekavās.

5 Latvijas padomju enciklopēdijā (LPE) un citos avotos saīsinātie vārdi citātos papildināti [kvadrātiekavās]. Ja dots tikai attiecīgā avota saīsinājums LPE, piemēri ņemti no 6. sējuma (1985), kurā ir šķirklis Lietuva. 
leksēma kņazs [5]. Šis vārds rada asociācijas ar slāvu kultūru (sal. 'vēst. karaspēka vadonis un kādas teritorijas valdnieks (slāvu un dažās citās zemēs no 9. līdz 16. gadsimtam); š̀̃ valdnieka tituls' (Ceplītis, Stengrevica 1980, 285), tāpēc tā izvēle cieši saistīta ar kontekstu, savukārt pārējie divi vārdnīcā iekl̦autie vārdi - kunigs un firsts - asociējas ar germāṇu kultūru (sal. firsts '(vācu Fürst) - no ķeizara vai karaļa tieši atkarīgs lielākas teritorijas valdnieks viduslaiku Vācijā ..' (Baldunčiks 1999, 225)). Citai kultūrvidei raksturīgas reālijas nosaukšanai „,.. var arī izlietot tehniskus nosaukumus, kultūras priekšmetu apzīmējumus, kad latviešu valodā vēl nav atrasts derīgs vārds vai arī nav atronams. Tā, piem., firsta latviešiem nav bijis; tātad šì jau diezgan parasta vārda vietā gan vislielākais valodnieks neizdomās derīgu latviešu nosaukumu. Daži gan domā kaut ko sevišķu izdomājuši, izlietodami firsta vietā vārdu kņazs: kņazs Bismarks. Bet tā jau, no vilka bēgdami, metamies lāča ķetnās" (Mīlenbahs 2009, 391). Kārḷa Mīlenbaha apgalvojums pilnībā attiecas arī uz vārda knazs lietošanu lietuviešu kunigaitis vietā.

Ar iepriekš aplūkoto personas nosaukumu saistīts vārdkopnosaukums didysis kunigaikštis. Mūsdienu lietuviešu valodas vārdnīcā tas definēts kā 'vēst. valdnieka tituls' (Keinys 2012, 120), bet vēstures vārdnīcā terminam ir četras nozīmes, no kurām pirmā attiecināta uz Lietuvu ('1. Lietuvas valsts valdnieka tituls .. '), savukārt pārējās trīs - uz senās Krievijas resp. slāvu kultūru (Asadauskienè et al. 2003, 101). Tas nozīmē, ka, tulkojot daudznozīmīgo nosaukumu un izvēloties piemērotāko atbilsmi mērķvalodā, ir jānovērtē kultūrvide (sal. didysis kunigaikštis 'vēst. dižkunigaitis, lielkunigaitis, lielkņazs' (Balkevičs et al. 1995, 101), bet turpat arī 'dižkunigaitis, lielkņazs' (250)). Grūtības sagādā ne tikai pamatkomponents kunigaikštis, par ko jau bija runa iepriekš, bet arī apzīmētājkomponents didysis un lielā sākumburta lietojums:

(2) Šā uzskata [par viendievību] pamatā ir Li e tuvas dižkun iga iša Ģedimina vēstule pāvesta delegātiem, kas rakstīta 14. gadsimta pirmajā trě̌dalāa, un tajā viņš ir uzsvēris domu par vienu dievu, ko ikviena tauta pielūdz savā veidā S 151; (2) Tajā [katedrālē] svinīgi tika kronēti L i e t u v a s d $i \check{z}$ k u n i ga i š i, sākot ar Vitautu un beidzot ar Žīgimantu Augustu AKL 5; (3) Viļna pirmo reizi vēsturiskajos avotos - Diž ku nig a iša Gedimina vēstulēs - minēta 1323. gadā .. AKL 2; (4) Traku Salas pil̄ 1430. gada oktobrī nomira Li etuvas li elkunigaitis Vitauts AKL 17; (5) Leǵgenda vēsta par Vilñas dibinātāju dižo Li e tuvas kuniga i t $i$ Ģediminu, kurš redzējis sapni - uz viena no uzkalniem stāv un gaudo dzelzs vilks AKL 5; (6) Galv[enais] li e l kn a z a varas balsts bija feod[ālās] zemes īpašnieki LPE 157; (7) L i e l kņazs Jagailis noslēdza ar Poliju Krēvas ūniju (1385) LPE 154; (8) .. ìpaša draudzība izveidojās ar Klaipēdas šauļiem (par šo leksēmu sk. tālāk) un Vi t a u t a L i e l à gimnāzijas audzēkņiem un skolotājiem, pie kuriem Liepājas nodaļas sportisti un koris vairākkārt viesojās LL 82.

Analizētie teksti liecina, ka latviešu valodā visbiežāk lieto salikteni, kas darināts vai nu ar poētiskas nokrāsas īpašības vārdu dižs, vai neitrālo liels (vārdkopās attiecīgi formas ar noteikto galotni dižais, lielais) pirmajā salikteņa dal̦ā, taču, kā redzams no iepriekš teiktā, arī vārdnīcā nav konsekvences, tāpēc grūti uz to cerēt 
tekstos. Par iemeslu ir tas, ka lietuviešu valodas didis (tā forma ar noteikto galotni ir didysis) latviski tiek tulkota kā liels, dižs, dižens, arī spēcīgs (Balkevičs et al. 1995, 101). Iespējams, lai izceltu kādreizējās Lietuvas valsts varenību, izvēlēts neitrālā īpašības vārda liels sinonīms dižs (Rauhvargers 2002, 205-206) [1; 2; 3; 5]. Vienā no tekstiem konstatēta vārdkopa dižais Lietuvas kunigaitis, kas precīzi atbilst avotvalodas izteiksmei [5], taču nav tik êrta kā saliktenis, tāpēc netiek plaši lietota. Mērķvalodas tekstā vienā no avotiem (enciklopēdijā) konstatēts salikteņa ar pamatkomponentu knazs lietojums [6; 7], kā arī mūsdienu kontekstā lietotais Lietuvas dižkunigaiša vārds ǵimnāzijas nosaukumā $[8]^{6}$ - apzīmētājs Lielais kopā ar personvārdu Vitauts (pareizi būtu Vītauts; sal. Vytautas Didysis). Gan lietojot sugasvārdu dižkunigaitis, gan paplašināto vārdkopu Lietuvas dižkunigaitis, kur identificēšanas funkciju veic īpašvārds Lietuva, lielais sākumburts nav nepieciešams, taču, saucot kunigaiti vārdā, tā pielikums (pievārds) - ar īpašības vārdu izteiktais apzīmētājs Dižais (vai Lielais) - jāraksta ar lielo sākumburtu [8] (sal. Vytautas Didysis (Dobelienè 1998, 57)).

Bezekvivalenta leksikas grupā ietilpst vēsturiskās reālijas nosaukums kunigaikštyste (arī tā derivatīvais sinonīms ${ }^{7}$ kunigaikštija). Abiem šiem atvasinājumiem lietuviešu valodā ir divas nozīmes: 'vēst. 1. apgabals vai valsts, kur valda kunigaitis; 2. kunigaiša vara' (Keinys 2012, 342), abi tie sastopami arī senās Lietuvas valsts nosaukumā. Par nosaukuma variantiem avotvalodā atzinumu ir sniegusi Valsts lietuviešu valodas komisija (liet. Valstybiné lietuviu kalbos komisija): „No valodas viedokḷa pareizi ir abi nomenklatūras vārda varianti gan kunigaikštija, gan kunigaikštystè. Neviens no tiem nevar tikt uzskatīts par nenormatīvu. Taču, runājot par Lietuvas valsts nosaukumu, ieteicamāks variants Lietuvos Didžioji Kunigaikštystè. .. šim nosaukumam lietuviešu avotos ir ilgāka lietošanas tradīcija, valodas skatījumā tas labāk atbilst arī mūsdienu valstu nosaukumu veidošanas modelim." (Konsultacija) Tas, ka lietuviešu valodā lieto atvasinājumus ar izskaņām -ystè un -ija, redzams lietuviešu-latviešu vārdnīcā: kunigaikštija žr. kunigaikštystė; kunigaikštystè '1. kunigaitija; kṇaziste; 2. kunigaiša (kuniga, kñaza, firsta) valdīšana’ (Balkevičs et al. 1995, 250). Taču arī latviešu valodā iespējams lietot divus atvasinājumus: bez tulkojošajā vārdnīcā iekḷautā kunigaitija, arī ar -iste darināto kunigaitiste 'vēst. teritorija, kurā valda kunigaitis' (Ceplītis, Stengrevica 1980, 490) (sal. kņaziste 'vēst. teritorija, kurā valda kņazs' (Ceplītis, Stengrevica 1980, 285)). Lietuviešu-latviešu vārdnīcā īpašības vārda didis iekļautās atbilsmes nedaudz atšķiras: 'didžioji kunigaikštystè vēst. lielkņaziste, lielkunigaitiste' (Balkevičs et al. 1995, 101). Izveidojusies situācija nepalīdz atrisināt radušos dilemmu, tāpēc izvēle paliek autoru ziṇā:

(3) Tagadējās Lietuvas gerbonis sakņojas tālajos viduslaikos un lietuviešiem atgādina par kādreizējo Lietuvas Dižkunigaitijas varenību AKL 2; (2) .. paplašinoties Lietuvas Dižkunigaitijai,

${ }_{6}$ Salīdzinājumam universitātes nosaukums tradicionāli ir Vìtauta Dižā Universitāte (liet. Vytauto Didžiojo universitetas) (NVK 117) (sal. Vytautas Didysis - Vìtauts Dižais (Balkevičs et al. 1995, 101)).

7 „Sinonīms, darināts no tā paša pamatvārda ar atškirīgiem vārdveidojošajiem afiksiem, kuriem ir tā pati vārddarināšanas nozīme un tā pati vai tuva leksiskā nozīme." (Kvašytè $2005,60)$ 
par lietuviešiem sāka saukt visus š̄is kunigaitijas iedzīvotājus, neņemot vērā viņu tautību MB 41; (3) Tāpēc [ka viņiem nav impēriskā instinkta] arī lietuvieši kā etnoss un kā tauta nav spējuši saglabāt savu Dižkunigaitijas valsti K 2009/11, 196; (4) 1605. gada septembrī pie Salaspils Lietuvas hetmaņa Jana Karola Hodkēviča komandētie 4000 Li e tuvas li elkunigaitijas karavīri smagi sakāva 11000 vīru lielo Zviedrijas karal̦a armiju, kas bija ieradusies ieņemt Rīgu LL 9; (5) Jaunveidojamai Vilņas Universitātei jezuīti izvirzīja lielus mērķus - izplatīt zinātni un katolicismu ne tikai L i e t u vas L i elk u n iga i t ij $\bar{a}$ un tai tuvās zemēs .. LV 84; (6) Ap 1240 radās liet[uviešu] agrā feod[ālā] valsts Li et uvas li elknazis te LPE 157 (enciklopēdijā ir arī atseviškss šķirklis Li e tuvas li el kn a zis te LPE 155); (7) 1562. gada martā pēdējais Livonijas ordeña mestrs Gothards Ketlers Rīgas pilī svinīgi nolika savas pilnvaras un nodeva uzticības zvērestu Polijas karaļa pārstāvim Li e tuvas li elkņazistes (l i elkunigaitijas) (tālāk tekstā autors abus variantus lieto atsevišksi) lielkancleram un Vilņas vojevodam Nikolajam Radzivilam Melnajam LL 7; (8) Lietuvas tatāri ir etnisko

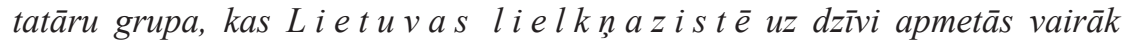
nekā pirms 600 gadiem K 2009/10, 197; (9) Dievnamu [Pažaislē] 17. gs. benediktiě̌u mūkiem uzcēla Li etuvas Dižās kunigaitijas kanclers Žīgimants Pacs, un tā ir viena no skaistākajām baroka arhitektūras celtnēm Lietuvā AKL 10; (10) Vèlāk Lietuva apvienojās ar Poliju, izveidojot $L$ i e $t u$ vas li el he rco $g$ is $t i$, kas savos ziedu laiko pletās no Baltijas jūras lìdz Melnajai jūrai S 125.

Latviešu valodas vārdnīcā iekḷautā atvasinājuma kunigaitiste vietā tekstos konstatēts tikai kunigaitija resp. tulkojošajā vārdnīcā fiksētais ekvivalents. Valsts nosaukumā tāpat kā iepriekš analizētajā personas nosaukumā lieto salikteņus ar atkarīgajiem komponentiem liel- un diž-, taču, atšķirībā no valdnieka kā personas nosaukuma, dominē neitrālais īpašības vārds [4-8; 10], savukārt stilistiski marķētais divos gadījumos ir salikten̄̄ [1-3] un vienreiz vārdkopā [9]. Runājot par Lietuvas valsti, vienā piemērā konstatēts saliktenis ar pamatkomponentu hercogiste [10] (sal. 'vēst. hercoga valsts; atsevišķa feodālās valsts daļa' (Ceplītis, Stengrevica 1975, 194), bet trijos - knaziste [6-8]. Konsekventa leksēmas ar -ija izvēle varētu būt saistīta ar vēlmi uzsvērt Lietuvas kultūras specifiku (sal. citi valstu vai valsts dal̦u nosaukumi darināti ar -iste: hercogiste, knaziste, cariste). Jāpiebilst, ka latviešu valodā vārds kunigaitija konstatēts arī pārnestā nozīmē - grāmatas Lietuvas vēsture nodaļas nosaukumā Bīskapa M. Valančus , garīgā k u n i g a i t i j a” LV 118.

Pie vēsturiskajām sabiedriski politiskās dzīves reālijām pieskaitāma arī Lietuvas administratīvi teritoriālā dalījuma vienība apylinké '2. vēst. mazākā administratīvā vienība' (Keinys 2012, 24) ${ }^{8}$. Atbilstošais lietuviešu nosaukums gan vienkārši pārrakstīts ar latviešu alfabēta burtiem, gan pārtulkots, taču izvēlētajam latviešu ekvivalentam ir cita nozīme, kas bez paskaidrojuma nebūs saprotama:

8 Sal. ,apylinkè - 1. Mazākā administratīvi teritoriālā vienība, ko padomju vara ieviesa 1940. g. beigās seņūnijas vietā. Pastāvēja (ar pārtraukumu 1941-1944) līdz 1994 (kamēr tika atjaunotas seņūnijas)" (Račis 2001, 647). 
'3. ap̄iliņ̧⿻̧一 ciems (Lietuvas administratīvi teritoriālā iedalījuma pamatvienība)' (Balkevičs et al. 1995, 36):

(4) Vietējie valsts varas orgāni rajonos, pils[ētās], pilsētu raj[onos], c[iema]tos un a p i li n kos ir tautas dep[utātu] padomes, ko ievēlē uz 5 gadiem LPE 156; (2) Seņūnijas tika ieviestas 1994. gada 7. jūlijāa, aizvietojot a p i l i $n k$ a s V.

Raksta problemātikas kontekstā pārsteidzoši, ka lietuviešu valodas vārds apylinkè, kas ir sieviešu dzimtes un tika tulkots kā apgabals, šajā citātā sastopams tik neparastā formā - saglabājot lietuvisko sakni, tikai mainot dzimti. Mūsdienās vārdam apylinkè lietuviešu valodā ir vairākas nozīmes, bet visas tās latviešu valodā tiek tulkotas, jo nav bezekvivalenta leksika (sal. '1. apkārtne, apkaime; 2. iecirknis ..' (Balkevičs et al. 1995, 36). Savukārt gan Latvijas padomju enciklopēdijā [1], gan interneta enciklopēdijā [2] konstatētie varianti neatbilst vārdnīcā fiksētajam vārdam.

Vēsturiskās sabiedriskās dzīves reālijas ir arī dažādas naudas vienības, piem., senās Lietuvas valsts laikus atgādina nosaukums auksinas '1. zelta, vēlāk sudraba senās Lietuvas monēta; 2. 1919-1922. g. Lietuvas papīnauda, atbilst Vācijas markai' (Keinys 2012, 63). Tas iekḷauts lietuviešu-latviešu vārdnīcā: 'vēst. auksins (naudas zìme dažos Lietuvas vēstures posmos)' (Balkevičs et al. 1995, 66):

Valstī vèl aizvien [1922. g.] apgrozībā bija ostmarkas, kuras Lietuvas vara nosauca par ,z e l t $\bar{l}$ t $\bar{a} m$ ” (liet. a u k s i n a s) LV 163.

Piemērā redzams, ka vispirms apspēlēta šī nosaukuma etimolog̣ija lietuviešu valodā (sal. auksas 'zelts'), savukārt iekavās kā paskaidrojums minēts lietuviešu valodas vārds.

Par vēsturisko bezekvivalenta leksiku uzskatāmi arī naudas vienību nosaukumi litas un centas. Gan papīrnaudas, gan monētu (sīknaudas) nosaukumi ir iekḷauti latviešu valodas svešvārdu vārdnīcā, taču tas darīts atšksirīgi. Lietuvai raksturīgais nosaukums lits '(liet. litas) Lietuvas naudas pamatvienība' (Baldunčiks 1999, 440) minēts, nenorādot tā cilmi, taču definīcijā ir valsts nosaukums (sal. 'lits (naudas vienība)' (Balkevičs et al. 1995, 268)). Savukārt plašāk, ne tikai Lietuvā, izplatītais cents fiksēts ar precīzu cilmes norādi, taču bez attiecinājuma uz konkrētu valsti: '(ang. cent < lat. centum 'simts') naudas vienība (lielākas vienības simtdaļa) vairākās valstīs' (Baldunčiks 1999, 122) (sal. 'cents (naudas vienība)' (Balkevičs et al. 1995, 86)). Šie nosaukumi ir populāri Latvijas preses izdevumos, kā arī dažādos citos tekstos, kur bieži tiek rakstīts par ekonomikas aktualitātēm:

(5) Satversmes seims 1922. gada 9. augustā pieņēma likumu par naudas vien̄̄bu. Likums pasludināja, ka Lietuvā naudas vienība ir lits ar zelta segumu, li ts sastāv no 100 c e n ti e $m$ LV 164; (2) L its - Lietuvas Republikas (1918.-1940. g. $)^{9}$ nacionālà naudas vienība (saīsināti Lt), kas bāzējas uz zeltu (1 Lt = 100 c e $n$ t i) NL 81; (3) Dažkārt tirgošanā gan parādoties lētās desas no Polijas, kas maksā vienu vai divus li t u s. N 20.04.2009., 34; (4) Kioskos

9 Par Lietuvas naudasvienību lits un cents atkal kḷuva 1993. gadā resp. jau pēc citētā avota izdošanas. 
izsniegtā viena aizdevuma maksimālais apjoms būs 2000 lit i (408 lati) N 25.08.2008., 6; (5) Šobrīd summa, kas jāmaksā par cūkgalu un liellopa gal̦u, nav mainījusies jau kopš pagājušā gada: par kilogramu (dzīvsvarāa) govju gal̆as maksājam trīs li t us (60 santīmu), par vērša galu - 4,50 (90 santīmu), cūkgaļu - 4,20 (aptuveni 87 santìmi) N 20.04.2009., 34; (6) Ârvalstu tiešās investīcijas Vilņas apgabalā šā gada sākumā sasniedza 20,27 miljardus li t u (5,88 miljardi eiro) .. N 02.06.2008., 6.

Lietuvas naudas vienību nosaukumu lietošana nesagādā grūtības, jo tie ir tradicionāli labi zināmi. Analizējot latviešu tekstus, redzams, ka praksē minētās summas publikāciju autori pārrēḳina Latvijas naudas vienībās (tiesa gan, tas attiecas pārsvarā uz litiem, ne uz centiem) [4; 5] vai Eiropas Savienības naudas vienībās [6], kamēr Latvija un Lietuva nebija kḷuvušas par vienotās valūtas zonas valstīm (attiecīgi 2014. un 2015. gadā). Līdz tam laikam nosaukums lits tiktu uzskatīts par aktualizēto resp. pēcpadomju laikposma Lietuvas Republikas oficiālās valūtas nosaukumu. Par Lietuvas valūtu kḷūstot eiro, tas atkal atgriežas vēsturisko sabiedrisko reāliju nosaukumu statusā, savukārt leksēma cents joprojām nosauc mūsdienu Lietuvas valūtu, jo tā sauc arī Eiropas kopvalūtas sīknaudas vienību. Jāpiebilst, ka lietuvieši sarunvalodā nereti mēdz lietot salikteni eurocentas, tādējādi uzsverot notikušās izmaiņas.

Lietuviešu svešvārdu vārdnīcā četras nozīmes ir aizguvumam no latīṇu valodas statutas 'lot. statutum - nustatymas' (Kaulakienè et al. 2013, 772). Analizējot lietuviešu vēsturisko bezekvivalenta leksiku, jāpievērš uzmanība pirmajai nozīmei '1. vēst. likumu krājums, tiesas likumkrājums: Lietuvos Statutas ..' (Keinys 2012, 731). Valsts pamatdokumenta nosaukums iekḷauts lietuviešu-latviešu vārdnīcas šķirklī statutas - '2. vēst.: Lietuvos statutas - Lietuvas statūts' (Balkevičs et al. 1995, 468), kuru mūsdienās lieto galvenokārt tekstos par Lietuvas vēsturi:

(6) Spēkā palika arī L i e tu vas S t a t $\bar{u} t s$, bet polvu valodas lietošana tika aţ̦auta pašvald̄̄bas institūicijās, apriņķa administrācijāa, zemākajā tiesu sistēmas līmeñ̄, izglītības sistēmāa, savukārt Vilņas Universitātē tikai tajā laikāa pārgāja no pasniegšanas latīnu valodā uz mācīšanu poḷu valodā LV 109; (2) L i e tuvas s t a t $\bar{u} t i$ - Lietuvas lielknazistes (par to sk. nosaukuma kunigaikštystè aprakstu) feodālo tiesību kodeksi 3 redakcijās (1529., 1566. un 1588.) LPE 169.

Citētajos piemēros redzamas divas būtiskas atšksirības - lielo sākumburtu lietošana un skaița vārdformas izvēle. Kaut gan tulkojošajā vārdnīcā ar lielo sākumburtu rakstīts tikai valsts nosaukums, atbilstoši lietuviešu valodas pareizrakstības normām īpaši svarīgu dokumentu nosaukumos visi vārdi jāraksta ar lielajiem sākumburtiem (Dobelienẻ 1998, 59) (kā piemērs minēts arī nosaukums Lietuvos Statutas) [1]. Savukārt, izvēloties daudzskaitli statūti [2], šajā gadījumā autoru nolūks acīmredzot bijis apkopojoši nosaukt visas šī Lietuvas valstij svarīgā dokumenta redakcijas. Taču ārpus konteksta adresāts tādu lietojumu varētu pārprast, ņemot vērā, ka šim svešvārdam gan lietuviešu, gan latviešu valodā ir vairākas nozīmes (sal. statūti '[visdusl. lat. statutum < lat. statuere 'noteikt'] 1. jur. tiesību normu kopojums; 2. noteikumi, kas reglamentē kādas organizācijas 
uzbūvi un darbību, kā arī visu organizācijas locekl̦u rīcību: ${ }^{10} 3$. ordena statūti ordeņa apraksts, kā arī priekšraksts par to, kādā kārtībā ar šo ordeni apbalvo un kā tas nēsājams' (Baldunčiks 1999, 749)) (zināmu ietekmi var atstāt mazā sākumburta lietojums).

Lietuvas vēsturisko reāliju nosaukumu kopā iekḷauta persona, kas nosaukta ar salikteni knygnešys '1. vēst. drukas aizlieguma laikos ārzemēs iespiesto lietuviešu grāmatu nesējs pāri robežai un to izplatītājs; 2. grāmatu iznēsātājs, izplatītājs' (Keinys 2012, 319). Lietuviešu-latviešu vārdnīcā piedāvā šo leksēmu atveidot ar divām vārdkopām 'vēst. grāmatu iznēsātājs; (aizliegtu) grāmatu izplatītājs' (turpat minēts arī atvasinājums knygnešystè ar plašāku komentāru '(cara cenzūras aizliegtu) grāmatu iznēsāšana (izplatīšana)' (Balkevičs et al. 1995, 235)), savukārt tekstos vēsturiskā reālija parasti tiek skaidrota aprakstoši:

(7) Pamudinājis nepieñemt cara varas piedāvātās grāmatas, bīskaps [Motiejus Valančus] Austrumprūsijā slepeni noorganizèja lietuviešu preses iespiešanu, izmantojot latīnu alfabēta burtus, kā arī nelegālu to izplatīšanu Lietuvā. Izveidojās spēcīga grāmatu kontrabandas jeb "grāmatu ne sēju" [parindē: Grāmatu nesēji (knygnešiai) - cilvēki, kas drukas aizlieguma laikā (1864-1904) kontrabandas cel̦ā Krievijas paklautībā esošajā Lietuvā ienesa ārzemēs iespiestas grāmatas un periodiskos izdevumus. (Tulk. piez.)] kustība LV 126; (2) Savus bērniņus mācījām mājās slepenās skolās, bet lietuviešu grāmatas un mācību grāmatas a i z li e g to grāmatu i z p la t $\bar{l}$ t āji (lietuviski knygnešiai* [parindē * lietuviešu knygnešys (burtiski ,grāmatu nesējs" - ̌̌o vārdu citas tautas nezina)] nelegāli atgādāja no Prūsijas SKM 18; (3) Noteikti vērts apskatīt .. klēti Ustrones ciemā, kur iekārtots cara laika aizliegto grāmatu izplatītāja J. Tuma-Vaižganta muzejs AKL 15.

Lai pēc iespējas labāk iepazīstinātu ar šo reāliju, autori (tulkotāji) reizēm sniedz papildu komentārus parindēs. Jāpievērš uzmanība šī vārda nozīmes maiņai lietuviešu valodā padomju laikposmā, kad ,.. daži vārdi ieguva jaunas leksiskās nozīmes vai nozīmju nokrāsas, kas ir saistītas ar citas nozīmes pieškiršanu ar tiem nosauktajiem priekšmetiem. Piem., knygnešys senāk nozīmēja ,slepenu lietuviešu grāmatu nesēju pāri robežai”, bet pēckara gados sākts lietot ,grāmatu izplatītāja” nozīmē (senākā nozīme jau kḷuva par semantisko historismu)" (Palionis 1979, 301). Šì nozīme kā otrā fiksēta lietuviešu valodas vārdnīcā. Leksēmai knygnešyss kā vienam no lietuviešu kultūrvides vēsturisko reāliju nosaukumiem pievērsta uzmanība sastatāmās stilistikas pētījumos (Kvašytė, Čepaitienè, Župerka 2006, 45). Savukārt mūsdienās šis vārds tiek lietots vēl citā nozīmē, kas dal̦ēji atbilst Jona Paļoņa (Jonas Palionis) minētajam semantiskajam historismam - pārnestā nozīmē un/vai sarunvalodā tā sauc cilvēku, kurš piegādā vai sagādā kādam grāmatas, bet tas nav viņa darbs vai pienākums, drīzāk brīvprātīgs pakalpojums.

Visu aplūkoto vēsturisko sabiedriskās dzīves reāliju nosaukumu lietojumgadījumi liecina, ka nav vienotas nostājas, kā atveidot cittautu vēstures reāliju

10 Šajā nozīmē lietuviešu valodā lieto pašcilmes atvasinājumu ịstatai (Keinys 2012, 731). 
nosaukumus. Tas paliek adresantu resp. tekstu autoru un/vai redaktoru zin̄ā, savukārt katrs no viṇiem acīmredzot balstās uz personīgo pieredzi un situācijas izpratni.

\section{Aktualizēto reāliju nosaukumi}

Svarīgāka nekā vēsturisko sabiedriskās dzīves reāliju nosaukumu lietošana (tos biežāk lieto terminu funkcijā) ir savulaik vēsturisko, taču mūsdienu valsts dzīvē savu nozīmi atguvušo vārdu lietošana. Vēsturisko apstākḷu dēḷ līdz 1990. gadam liela daļa senajai Lietuvas valstij raksturīgo reāliju (valsts simbolikas u. tml.) nosaukumu funkcionēja tekstos par vēsturi, bet vārdnīcās bija fiksēti ar norādēm par to statusu, piem., arh., novec., vēst., reizēm arī ar nozaru norādēm, bet tādos gadījumos leksēmas neaktualitāte uzsvērta definīcijās (plašāk par historismiem kā pasīvo leksiku sk. Vilkaitè, Kvašytė 2006).

Aktualizētas ir reālijas, kas raksturo oficiālo valsts tēlu un atšķir Lietuvu no citām valstīm, savukārt valodnieciskā skatījumā svarīgi ir gan šo reāliju nosaukumi avotvalodā, gan to lietošana mērķvalodā. Pie bezekvivalenta leksikas pieder nosaukums Vytis (1. LDK (1336-1795), Lietuvas valsts (1918-1940, nuo 1990) ǵerbonis .. (Račis 2014, 321)). Lietuviešu valodas vārdnīcā šim vārdam fiksētas trīs nozīmes, taču tikai viena no tām ir aktualizēta: '1. vēst. sūtnis jāšus uz zirga; 2. vēst. senais varonis jāšus uz zirga; 3. Lietuvas valsts ǵerbonis, kurš attēlo valdnieku jāšus uz zirga'11 (Keinys 2012, 939) (sal. 'Vītis (Lietuvas valsts gerbonis)' (Balkevičs et al. 1995, 583)). Pirmais šo nosaukumu lietuviešu valodā, tiesa gan, ne gerboņa, bet tajā attēlotā jātnieka nosaukšanai 19. gadsimta vidū izmantojis Simons Daukants ${ }^{12}$; uz ǵerboni to 1884. gada mēnešrakstā Aušra ${ }^{13}$ mēǵinājis attiecināt Mikalojs Akelaitis ${ }^{14}$ (Račis 2007, 11):

(8) Vìtis - tā lietuvieši sauc savu galveno heraldisko zìmi - ir jātnieks sudraba bruñās uz sarkana fona ar sudraba zobenu, paceltu virs galvas AKL 2; (2) Lietuvas valsts gerbonis - Vīt is, jātnieks sarkanā fonā, ir viens no vecākajiem valsts gerboņiem Eiropā NVK 75; (3) Izvēloties valsts karoga krāsas (dzeltena, zaļa, sarkana), notika atteikšanās no LLK [Lietuvas Lielkunigaitijas - R. K.] valdnieku izmantotā karoga, bet gerbonis - balts $V \bar{i}$ t is uz sarkana fona - palika tas pats LV 162; (4) .. Jelgavas lietuviešu kultūras biedrība „,Vy t i s” LL 117; (5) Plaša bija Latvijas lietuviešu sporta apvienība „,Vyt i s” (,Jātnieks”-Lietuvas simbols) .. MVL 52.

Lai nosauktu Lietuvas valsts ǵerboni, gan vārdnīcās, gan tekstos gandrīz vienmēr lieto paskaidrojumus - parasti uzsver nosauktās reālijas funkcijas $[1 ; 2]$ vai apraksta tās izskatu [3]. Īpašvārds Vytis ir populārs dažādos simboliskajos

11 Definīcijā nosauktas dažādas personas: '1. istor. raitas pasiuntinys; 2. istor. raitas senovès karžygys; 3. Lietuvos valstybès herbas, vaizduojantis raitą valdovą'.

12 Simonas Daukantas (1793-1864) - vēsturnieks, apgaismības un tautas atmodas darbinieks (Račis 2003, 529).

13 „Aušra“ - pirmais tautiskais lietuviešu mēnešraksts, saukts par laikrakstu, ko 1883.-1886. gadā izdeva Ragainē un Tilzītē (Račis 2002, 299-300).

14 Mikalojus Akelaitis (1829-1887) - sabiedriskais un kultūras darbinieks, rakstnieks, valodnieks (Račis 2001, 223). 
nosaukumos Lietuvā un ārpus Lietuvas robežām: Latvijā ir kultūras biedrība un sporta apvienība [sal. 4; 5], Kanādā sporta klubs Toronto (tas iekḷauts Kanādas lietuviešu organizāciju rokasgrāmatā (KLOŽ 2002)) u. tml. Simboliskajos nosaukumos visbiežāk lieto avotvalodas vārda formu (parasti pēdiṇās), taču reizēm papildus tiek dots vārda tulkojums [5].

Aktualizēts vārds Vytis ir ne tikai Lietuvas valsts gerboņa nosaukumā, bet arī vārdkopnosaukumos, piem., vārdnīcā iekḷauta vārdkopa Vyčio kryžius ${ }^{15}$ ar skaidrojumu 'Vīša (Vīta) krusts (Lietuvas ordenis)' (Balkevičs et al. 1995, 583). Samērā liela šì Lietuvas valsts apbalvojuma nosaukumu dažādība konstatēta tekstos:

(9) 1920. gad̄̄ to [pirmo Lietuvas Republikas apbalvojumu] pārdēvēja par Jätnieka Krustu (Vyti e s Kryžiu s) ar un bez zobeniem ar trim šķirām, no kurām augstākā bija trešā LatV; (2) Kareivjiem šajā laikā nodibināja ìpašu atsevišksu apbalvojumu - Jā tn i e ka Krus tu (Vy č i o K r y ži u s) ar trim šķirām LatV; (3) 1930. gadā š̄̄ ordeņa variantam ar zobeniem (Vy č i o K r y ži a u s o r d i n a s) noteica piecas šķiras, bet ar to apbalvoja tikai virsniekus LatV.

Ordeña nosaukumi tiek tulkoti, iekavās kursīvā minot avotvalodas formu [1; 2], bet tekstā lietojot tikai nomenklatūrvārdu ordenis [3]. Tāds atveidojums atšksiras no vārdnīcas atbilsmes, taču visi trīs piemēri ir no viena teksta. Lai pārliecinātos, vai to var uzskatīt par tendenci, vajadzētu izskatīi lielāku piemēru kopu (pagaidām tādu izveidot nav izdevies).

Mūsdienās augstākā Lietuvas valsts apbalvojuma nosaukumā lieto arī iepriekš aplūkoto vēsturisko bezekvivalenta vārdkopnosaukumu didysis kunigaitis: Didžiojo Lietuvos kunigaikščio Gedimino ordinas (lietuviešu valodā pieņemtā lielo sākumburtu lietošana (Dobelienè 1998, 59) atšķiras no latviešu valodas, kur ar lielo sākumburtu ir jāraksta visi vārdi ordeņu nosaukumos, izņemot vārdu ordenis (Laugale, Šulce 2012, 82)). Tas attiecas arī uz citvalstu apbalvojumu - gan vēsturiskajiem, gan mūsdienu - nosaukumiem (Laugale, Šulce 2012, 62), taču latviešu valodas tekstos šî Lietuvas ordeņa nosaukums, tāpat kā iepriekš aplūkotais personas nosaukums (vārdkopa), lietots dažādi:

(10) Lietuvas Dižkunigaǐ̌a Ģedimina ordenis ir Lietuvas prezidenta apbalvojums, kas tika izveidots godinot Lietuvas pilsonus par sasniegumiem sabiedriskā un valsts labā V; (2) 12. decembra vakarā sešdesmit sešu gadu vecumā no šās pasaules atvadījies Nacionālās kultūras un mākslas prēmijas laureāts, dzejnieks, eseists, dramaturgs, literatūras kritiķis un tulkotājs, Li etuvas Dižkunigaiša Gedimina ordeņa c e turtās pakāpes kavalieris Sigits Geda (Sigitas Geda) K 2009/1, 198; (3) Dzejnieks, kritikgis, Li etuvas kunigaiša Gedimina IV pakāpes ordeña kavalieris Sigits Geda atzīts par vainīgu meitai Uršulei nodarītajos miesas bojājumos .. K 2008/11, 187; (4) Sakarā ar Lietuvas Republikas 10 gadu jubileju 1928. gadā tika nodibināts vēl

15 Tā saīsināti mēdz saukt vienu no augstākajiem Lietuvas valsts apbalvojumiem - Vyčio kryžiaus ordinas [Vyša krusta ordenis]. 
viens apbalvojums - Li e lās Li etuvas kunigaiša Gedimina orde n is (Didžiojo Lietuvos Kunigaiščio Gedimino ordinas). To piešķıira par izcilu darbu valsts un sabiedrības labā. Ordenis nodēvēts par godu lielkunigaitim Gediminam, kas 1321. gad̄̄ ieņēma Kijevu un 1323. gadā nodibināja Viļnas pilsētu LatV.

Avotvalodas forma atbilstoši prasībām atveidota tikai vienā piemērā [1], visos citos gadījumos lietojums variē: vārdkopas didysis kunigaikštis vietā lieto tikai kunigaikštis. Pārpratumus rada arī vārdu kārta, piem., īpašības vārda lielais sieviešu dzimtes ǵenitīvs (ja vien tā nav korektūras kḷūda) liek domāt, ka runa ir par Lielo Lietuvu, nevis par Lietuvas lielkunigaiti (pareizāk būtu dižkunigaitis (Balkevičs et al. 1995, 101)); plašāk par to sk. nosaukuma didysis kunigaikštis atveides aprakstu [4], savukārt vārds kavalieris jāsaista ar ordeņa pakāpi - ar attiecīgas pakāpes ordeni apbalvotais kḷūst par tā kavalieri [3].

Valsts sabiedrisko dzīves reāliju kopā uzmanība ir jāpievērš Lietuvas augstākās likumdevēja varas institūcijas (parlamenta) nosaukumam seimas, kura atbilsmi seims plaši lieto mutvārdu un rakstveida tekstos latviešu valodā. Tā ir viena no nedaudzajām piln̄̄gi saprotamām bezekvivalenta leksikas vienībām, 1̄stiem kultūraizguvumiem, kurš nostiprinājies latviešu valodā. Acīmredzot šo kultūraizgūšanu ir ietekmējis fakts, ka vārdu attiecina ne tikai uz vienu valsti resp. Lietuvu. Tas ir aizguvums no poḷu valodas (sal. sejm 'augstākā valsts likumdevējvaras iestāde Polijā un Lietuvā' (Baldunčiks 1999, 706)). Savukārt lietuviešu svešvārdu vārdnīcā nav norādes uz cilmi, doti tikai abu valstu parlamentu nosaukumi: Seimas '1. Lietuvas Republikas $\Delta$. Lietuvas parlaments. 2. Polijas Republikas $\Delta$. Polijas parlamenta apakšpalāta' (Kaulakienè et al. 2013, 733), bet lietuviešu valodas vārdnīcā '2. Lietuvā un dažās citās valstīs - parlaments'16 (Keinys 2012, 683):

(11) Saskaņā ar Lietuvas Republikas Konstitūciju, parlamentu sauc par S e i m u (lietuviski - S e i m a s) V; (2) Nepieciešamie paraksti jau ir savākti, un saskañā ar S e i m a noteikumiem komisija būs jāformē D 26.10.2005.; (3) Lietuvas politikiem joprojām nav izdevies izveidot jauno valdību, jo S e i $\mathrm{m}$ s otrdien noraidīja kreiso spēku izvirzīto premjera amata kandidātu Zigmantu Balčìti D 21.06.2006.; (4) Vēl pēc pārsimt metriem atrodas Neatkarības laukums (Nepriklausomybès aikštè), kur atrodas Lietuvas S e i m a èka AKL 6.

Kaut gan lietuviešu-latviešu vārdnīcā iekḷauts arī Latvijai raksturīgais nosaukums 'seimas - pol. seims; saeima (parlaments)' (Balkevičs et al. 1995, 439), praksē nav gadījies sastapt Lietuvas reālijas nosaukšanai latviešu valodā lietotu latvisko ekvivalentu Saeima. Savukārt par lietuviešu valodu un Lietuvas preses izdevumiem jāteic, ka tajos Latvijas parlamenta nosaukšanai l̦oti reti lieto latvisko bezekvivalenta vārdu. Visbiežāk, piemērojot substitūciju kā vienu no bezekvivalenta leksikas atveides principiem, to aizstāj ar lietuviešiem pierasto ekvivalentu Seims (par to sk. Kvašytė 2012, 148-150). Reizēm, galvenokārt

16 Pirmā nozīme - 'vēst. LDK kārtu, kā arī atsevišķu citu valstu varas orgāns; tā kongress' (sal. Steigiamasis seimas - Dibināšanas seims, reizēm arī Satversmes Seims). 
enciklopēdiskos izdevumos, blakus tiek minēts lietuviešu vārds [1], turklāt šis vārds nosauc ne tikai pašu institūciju, bet arī ēku, kur tā darbojas [7].

Aktualizēta pirmā no Lietuvas administratīvi teritoriālā dalījuma vienības nosaukuma seniūnija nozīmēm 'l. mazākā administratīvā vienība - rajona daḷa, ko pārvalda seņūns ${ }^{17}$ ', savukārt otra šī vārda nozīme - 'Lietuvas Dižkunigaitijas zemes īpašums, ko piešksir seņūnam bajāram' (Keinys 2012, 686) - joprojām saglabājas kā historisms. Lietuviešu-latviešu vārdnīcā fiksētas divas nozīmes, bet abas atveidotas tāpat - latviskojot resp. ar mīkstinātā līdzskaṇa burtu pārrakstot lietuviešu valodas vārdu: '1. vēst. seņūnija (zemāka lauku administratīvā vienība); 2. seņūnija (Lietuvas pilsētu administratīvā vienība)' (Balkevičs et al. 1995, 441) (jāpievērš uzmanība arī personas nosaukumam seniūnas, ko atveido tāpat):

(12) Lietuva ir iedalīta 10 aprinksos (apskritis), kas ir iedalīti 60 rajonu un pilsētu pašvaldībās (savivaldybè), kas ir sīkāk sadalītas 546 s e nु ū nij $\bar{a} s$ (seniūnija). Šāds administratīvi teritoriālais iedalījums tika radīts 2001. gadā V; (2) S e ņ ū n i j a (lietuviešu: seniūnija) vai stārastija ir mazākā Lietuvas administratīvi teritoriālā iedalījuma vien̄̄ba .. (3) S e ņ ū n i j u vada vēlèts stārasts V; (4) Krekenavas reǵionālā parka teritorija abpus Nevēžas ielejai aptver daḷu Krekenavas, Upītes, Naujamiesta un Ramīgalas s e ņ ū niju Panevēžas rajonā un daļu Survilišku s e ņ ū n i j a s Ķēdaiņu rajonā AKL 15.

Neraugoties uz to, ka latviešu avotos dominē latviskots lietuviešu nosaukums seņūnija, interneta enciklopēdijā kā šo vārdu sinonīmi parādās vārdi stārasts un stārastija. Ar norādi vēst. (vēsturisks, attiecas uz agrākiem laikiem) tie gan atrodami latviešu valodas vārdnīcā (Ceplītis, Stengrevica 1991, 171), taču nešķiet piemēroti, runājot par Lietuvas vēstures reālijām.

Lietuvā pēdējā laikā ir radušies jaundarinājumi - seniūnaitija, seniūnaitis. Pagaidām nav konstatēts to lietojums latviešu tekstos, taču domājams, ka pēc analog̣ijas ar iepriekš aplūkotajiem nosaukumiem tiktu saglabātas avotvalodai tuvas formas seņūnaitija un seņūnaitis.

Sabiedriskās leksikas grupā iekḷauts aktualizētais nosaukums šaulys ' 1 . kas prot šaut 2. mil. ar šauteni apbruņots karavīrs 3. brīvprātīgas militāras organizācijas (Lietuvas šauļu savienības) biedrs' (Keinys 2012, 800). Lietuviešu-latviešu vārdnīcā šì vārda pirmo divu nozīmju latviskās atbilsmes ir to tulkojumi, attiecīgi šâvējs un strēlnieks (ar norādi mil.) (Balkevičs et al. 1995, 504), savukārt trešās nozīmes ekvivalenta tajā nav. Tekstos tas parādās kā bezekvivalenta leksikas vārds šaulis (daudzskaitlī šauļi) ${ }^{18}$.

(13) .. īpaša draudzība izveidojās ar Klaipēdas š a u l i e m un Vitauta Lielā gimnāzijas audzēkņiem un skolotājiem, pie kuriem Liepājas nodaļas sportisti un koris vairākkārt viesojās LL 82; (2) Tādējādi konservatīvo, religiozo katoḷ zemnieku dēli - armijas leitnanti un "šs a u l $i$ " [parindē: Militarizēta

17 Mērķvalodā lietots vārds seņūns, lai saglabātu saikni ar analizējamo vārdu sen̦ūnija. Citās nozīmēs to var tulkot - vecākais.

18 Organizācijas biedru nosaukums mērķvalodā ir homonīms pilsētas Šauļi (liet. Šiauliai) nosaukumam - lietuviešu valodā tos šķir mīkstinājuma zīme, kura zūd, atveidojot abus nosaukumus latviešu valodā (rakstos par atšķirību var liecināt lielais sākumburts). 
strēlnieku organizācija, analoga Latvijas aizsargiem un Igaunijas Kaitseliit (Tulk. piez.)] demokrātisko nacionālās valsts modeli uz neilgu laiku nomainīja pret diktatūru, atteicās no demokrātijas par labu prezidenta A[ntana] Smetonas autoritārajam režìmam starptautiskās politikas apsvērumu dēl LV 172-173.

Kā redzams piemēros, reizēm lieto bezekvialenta leksēmu [1]. Ja autori nav pārliecināti par reālijas nosaukuma formu, izmanto pierakstu pēdin̄ās, kas signalizē, ka tekstā ir latviešu valodai neraksturīgs vārds, kā arī pievieno plašākus komentārus [2].

Tekstos par Lietuvu konstatēti divi aktualizēti Lietuvas partiju nosaukumi. Nosaukuma liaudininkai 'vēst. l̦audininki (darba tautas partija Lietuvā)' (Balkevičs et al. 1995, 263), kurš cēlies no liet. liaudis - tauta (par vārda tauta atbilsmēm lietuviešu un latviešu valodā sīkāk sk. Leonavičius 1997), norāde tulkojošajā vārdnīcā liecina, ka vārds jāuzskata par historismu. Taču arī mūsdienu Lietuvā ir partijas, kuru nosaukumā šis vārds tiek lietots (sal. liaudininkas 'polit. tautiski noskaņota sīkīpašnieku virziena vai partijas biedrs' (Keinys 2012, 364)) (arī vārdkopnosaukumos valstiečiai liaudininkai), tāpēc tas aplūkots kā aktualizēts:

(14) Maijā notika visu partiju un biedrību pārstāvju tikšanās (kreisos pārstāvēja biedrība „Giedra”, Rīgas lietuviešu savienība, sociālisti l a u di n i n ki un sociāldemokrāti), kurā tika mēgināts vienoties par delegātu nosūtīšanu uz Lietuviešu Seimu Petrogradā LL 49; (2) Lietuvas KP izvērsa cīnu pret klerikāliem un lla udininki em .. LPE 160; (3) .. llaudininki Lietuvas liberāli burž[uāziska] partija (1922-36); ofic[iālais] nos[aukums] Lietuvas Zemnieku l a u d i n i n k u savienība. Part[ijas] nos[aukums] cēlies no liet. liaudininkas - tautas partijas biedrs LPE 279; (4) Kreisais zemnieku ļaudininku [parindē: L,audininki (lietuviski liaudininkas nozīmē tautā populāru cilvēku) - liberālās Lietuvas Zemnieku l̦audininku savienības biedri. (Tulk. piez.)] bloks (vēlāk Lietuvas Zemnieku l̦audininku savienība - LZL̦S) ieguva 29 vietas, trešā palika Lietuvas Sociāldemokrātu partija (LSDP) LV 161; (5) Valdībā dominēja zemnieki ļ a u d in in ki ar ministru priekšsēèetāju M[īkolu] Sleževiču priekšgalā LV 169.

Otrs aktualizētais partijas nosaukums ir tautininkai - 'tautininki (politiska partija Lietuvā)' (Balkevičs et al. 1995, 522) (sal. tautininkas 'polit. partijas vai apvienības, kas uzsver tautiskumu, biedrs' (Keinys 2012, 835)). Partija, kuras nosaukumā ir šis vārds, pastāv arī mūsdienu Lietuvā - pēc 1990. gada Lietuviu tautininku sajunga [Lietuvas tautininku apvienība]:

(15) 1926 17. XII ta u ti n in ki kopā ar Kristīgo demokrātu part[iju] izdarīja valsts apvērsumu un nodibināja A. Smetonas faš[istisko] diktatūru LPE 159; (2) 1927 atlaida seimu, 1936 aizliedza visas burž[uāziskas] partijas, iznemot ta u t in inkus LPE 159; (3) .. t a u t in in ki (liet. tautininkas nacionālists) reakcionāras Lietuvas pilsētu un lauku buržuāzijas polit[iskas] partijas (Tautininku sav [i e n⿳亠丷⿵ a], dib[ināta] 1924 VIII) biedri LPE 1987, 542; (4) Kopā ar nākamajiem tautininkiem [parindē: Tautininki 
(liet. tautininkai - nacionālisti) - labēji nacionālistiskās Tautininku savienūbas biedri. (Tulk. piez.)], kas koncentrējās ap Antana Smetonas redigèto žurnālu "Viltis" ("Cerība"), kristīgie demokrāti cīnījās par lietuviešu valodas tiesībām Vilnnas bīskapijas baznīcām LV 135.

Abu partiju nosaukumi latviešu valodā visos gadījumos nosaukti ar latviskotiem avotvalodas vārdiem - attiecīgi ļaudininki un tautininki. Kā redzams, aplūkotajos piemēros saglabāta lietuviešu valodai raksturīgā izskaņa -ininki, kaut gan tās latviskā atbilsme, lai darinātu personas nosaukumu, būtu -inieki.

Viena no nozīmīgām mūsdienu Lietuvas sabiedriskās dzīves reālijām ir kustības nosaukums Sajūdis. Lietuviešu valodas vārdnīcā šim vārdam fiksētas divas nozīmes: '1. sapulcināta sabiedriska kustība, 2. sakustēšanās' (Keinys 2012, 670), bet lietuviešu-latviešu vārdnīcā tas latviskots, lietuviešu valodas garo patskani priedēklī aizstājot ar īso: 'pol. sajūdis (Lietuvas sabiedriski politiska kustība)' (Balkevičs et al. 1995, 432) (vārds sajūidis lietuviešu valodā ir veidots no prefiksālā darbības vārda sujudèti - 'sakustēties'):

(16) “S $\boldsymbol{a} \boldsymbol{j} \overline{\boldsymbol{u}} \boldsymbol{d} \boldsymbol{i} \boldsymbol{s}$ ” (liet. sajūdis kustība) sabiedriski polit [iska] kustība cīnai par Lietuvas valstiskuma reālu atjaunošanu ārpus PSRS, visu sab[iedrības] dzīves sfēru demokratizāciju. S. izveidojās 1988. Pēc uzvaras Lietuvas AP vēlēšanās 1990 Lietuvas Republikā tiek realizēti S. programmā paredzētie pārkārtojumi EV 1991, 158; (2) Lietuvas Pārkārtošanās kustība (S a j ū d i s) 1988. -1990. gadā [virsraksts] LV 260; (3) Politiķi, kas pirms 15 gadiem parakstīja Neatkarības deklarāciju, ir pārliecināti, ka šajā laikā Lietuva ir sasniegusi visus mērķus, ko bija izvirzījusi nacionālā atbrīvošanās kustība $S$ a j $\bar{u} d$ is D 11.03.2005.; (4) Viens no aktīvākajiem $S$ ajj $\bar{u} d i s$ biedriem žurnālists Vitaļus Zaikausks atceras, ka pirms 15 gadiem iedomājies moderno Lietuvu tieši tādu kā tagad D 11.03.2005.; (5) Sakiet, vai no kustības Sajū $d i \mathrm{~s}$ laikiem ir saglabājusies, teiksim tā, vecbiedru grupa, cilvēki, kas palaikam sanāk kopāe Jā, piedevām Sa j ū d is pastāv vēl tagad D 20.08.2009.; (6) Atmodas laikā [Arvīds Jozaitis] bijis $\mathrm{S}$ ą j ū d ž a $\mathrm{z}$ i ņ u redaktors, bet no 2004. lìdz 2009. gadam - kultūras atašejs Lietuvas generālkonsulātā Kaļiņingradā K 2009/10, 198; (7) Pēc pašas L. Lolišvili teiktāa, pēc ierašanās Lietuvā gaišreǵei kāds parādījis A. Brazauska un kādreizējā L $i$ e tu vas tautas frontes lìdera Vìtauta Landsberǵa fotogräfijas NRA 21.03.2003.

Šis nosaukums tekstos parasti tiek latviskots tā, kā ieteikts lietuviešu-latviešu vārdnīcā, vai aizstāts ar plašāku organizāciju raksturojumu [2], reizēm pievienojot iekavās avotvalodas formu [1]. Kā redzams no piemēriem, nereti rodas grūtības ar tā locīšanu [4]. Vienā gadījumā konstatēta aizstāšana ar Latvijas analogu Latvijas tautas fronte [7]. Šāda nosaukuma burtiska pārcelšana Lietuvas kontekstā, neskatoties uz to, ka iepriekš minētais Lietuvas kustības nosaukums jau iekḷauts tulkojošajā vārdnīcā, nav pamatots. Lietuvas nacionālās atbrīvošanās kustības Sajūdis nosaukums lietots arī simboliskajā - preses izdevuma - nosaukumā Sajūdžio žinios. Latviešu tekstā šis nosaukums tulkots, kaut gan tā nevajadzētu darīt, turklāt pierakstīts neprecīzi - būtu jābūt Sajūža ziņas [6]. 
Bezekvivalenta leksikas paraugs ir arī ar minēto sabiedrisko kustību saistītais nosaukums resp. šīs kustības dalībnieka un atbalstītāja nosaukums. Lietuviešulatviešu vārdnīcā iekļauti derivatīvie sinonīmi ar izskaņām -ietis un -ininkas sajūdietis un sqjüdininkas 'pol. sajūdietis (Lietuvas sabiedriski politiskās kustības dalībnieks, -ce)’ (Balkevičs et al. 1995, 432).

Aktualizētās sabiedriskās dzīves reāliju nosaukumus lieto latviskotā avotvalodas veidolā, piem., seņūnija, seņūns, šauļi, tautininki, ļaudininki, savukārt par kultūraizguvumu var uzskatīt Lietuvas parlamenta nosaukumu seims.

\section{Secinājumi}

Publikācijās latviešu valodā par Lietuvu un tās tautas vēsturi, pārsvarā enciklopēdijās, arī populārzinātniskajos, informatīvajos un preses izdevumos, visbiežāk sastopamas divas sabiedriskās dzīves reāliju nosaukumu grupas: 1) vēsturiskā leksika (historismi) un 2) aktualizētā leksika. Gan vēsturiskā, gan aktualizētā leksika nosauc valsts simbolus, dažādas personas pēc to statusa vai nodarbošanās, administratīvi teritoriālās vienības, naudas vienības, partijas, sabiedriskās kustības u. tml. Izanalizējot Lietuvas kultūrvidei raksturīgos nosaukumus, sauktus par bezekvivalenta leksiku, reizēm - par kultūraizguvumiem, noskaidrotas atveides likumsakarības. Piederība vēsturiskajai vai aktualizētajai leksikai neietekmē atveides paņēmienu izvēli. Lielākā atškirība saistīta ar to, ka aktualizēto leksiku lieto biežāk un dažādos tekstos, tāpēc tās atveide ir stabilāka. N̦emot vērā, ka sabiedriskās dzīves reāliju nosaukumi bieži tiek lietoti kā vēstures termini, īpaši svarīgi korekti lietot (atveidot) šos reāliju nosaukumus, piem., citvalstu resp. Lietuvas vēstures, politikas, kultūrvēstures u. tml. tekstos vai ar tām saistītā kontekstā, lai adresātam būtu saprotams teksts, bet netiktu zaudēta kultūrspecifika. Šo reāliju nosaukumu lietošana latviešu valodā atkarīga no avota, kurā šīs leksikas vienības fiksētas, kā arī no autoru skatījuma uz to lietošanu. Pārsvarā minētie lietuviešu nosaukumi tiek latviskoti, kaut gan reizēm tekstā konstatēti arī paskaidrojoši komentāri, tulkojumi, retāk - kultūraizstāšana.

\section{Saīsinājumi}

$\begin{array}{ll}\text { AKL } & \text { Apraugi kaimiņus lietuviešus! } \\ \text { D } & \text { Diena } \\ \text { EV } & \text { Vilks, Andris (red.). Enciklopēdiskā vārdnīca } \\ \text { K } & \text { Karogs } \\ \text { KLOŽ } & \text { Mažeikaitè, Rasa (sast.). Kanados lietuviu organizaciju žinynas } \\ \text { LatV } & \text { Latvijas Vēstnesis. } \\ \text { LL } & \text { Jēkabsons, Ēriks. Lietuvieši Latvijā } \\ \text { LPE } & \text { Jērāns, Pēteris (red.). Latvijas padomju enciklopēdija } \\ \text { LV } & \text { Eidints, Alfonss et al. Lietuvas vēsture } \\ \text { MB } & \text { Sabalausks, Aḷgirds. Mēs - balti } \\ \text { MitE } & \text { Iltnere, Astrīda (red.). Mitoloğijas enciklopēdija } \\ \text { MVL } & \text { Treija, Aldona, Dribins, Leo. Mazākumtautību vēsture Latvijā }\end{array}$




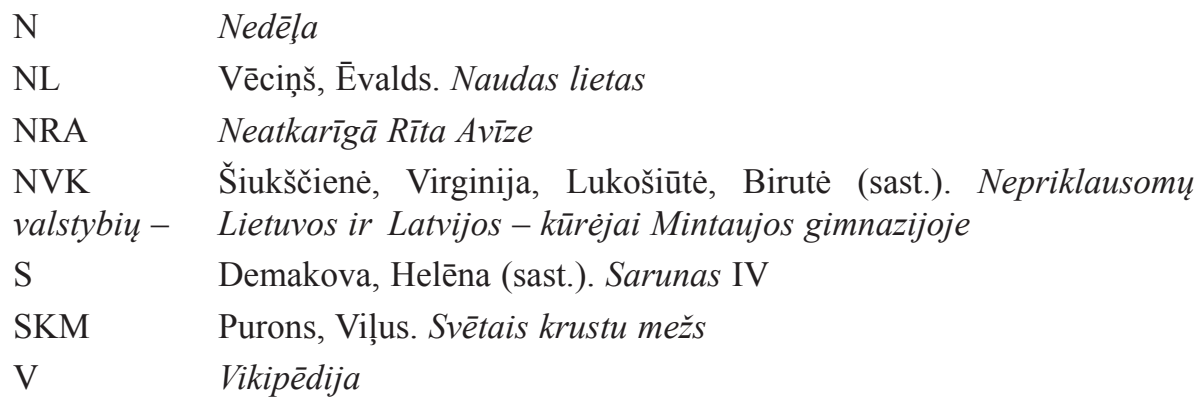

\section{Avoti}

1. Apraugi kaimiņus lietuviešus! Projekts “Apraugi kaimiņus”. Idea media, 2003 (informatīvs izdevums).

2. Asadauskienè, Nelè et al. 2003. Istorijos žodynas. Vilnius: Vaga.

3. Baldunčiks, Juris (red.). 1999. Svešvārdu vārdnīca. Rīga: Jumava.

4. Balkevičs et al. 1995. Lietuviešu-latviešu valodu vārdnīca. Rīga: Zinātne.

5. Ceplītis, Laimdots, Stengrevica, Melita (red.). Latviešu literārās valodas vārdnīca. 3. sēj. 1975; 4. sēj. 1980; 72. sēj. 1991. Rīga: Zinātne.

6. Demakova, Helēna (sast.). 2003. Sarunas IV. Lekcijas un diskusijas. Rīga: Jaunā akadēmija.

7. Diena (laikraksts).

8. Eidints, Alfonss, Bumblausks, Alfreds, Kulakausks, Antans, Tamošaitis, Mindaugs. 2014. Lietuvas vēsture. Rīga: Zvaigzne ABC.

9. Iltnere, Astrīda (red.). 1994. Mitologijas enciklopēdija. 2. Rīga: Latvijas enciklopēdija.

10. Jēkabsons, Ēriks. 2003. Lietuvieši Latvijā. Rīga: Elpa.

11. Jērāns, Pēteris (red.). Latvijas padomju enciklopēdija. 6. sēj. 1985; 9. sēj. 1987. Rīga: Galvenā enciklopēdiju redakcija.

12. Karogs (literārs žurnāls).

13. Kaulakienè, Angelè et al. 2013. Tarptautinių žodžių žodynas. Vilnius: Alma littera.

14. Keinys, Stasys (red.). 2012. Dabartinès lietuviu kalbos žodynas. Septintas pataisytas ir papildytas leidimas. Vilnius: Lietuvių kalbos institutas.

15. Kvašytė, Regina. 2005. Mokomasis terminologijos žodynèlis. Šiauliai: Všİ Šiaulių universiteto leidykla.

16. Latvijas Vēstnesis (laikraksts). Pieejams https://www.vestnesis.lv/ta/id/62403

17. Mažeikaitè, Rasa (sast.). 2002. Kanados lietuviu organizacijǔ žinynas. Torontas: Kanados Lietuvių Bendruomenè.

18. Neatkarīgā Rìta Avīze (laikraksts).

19. Nedēḷa (informatīvi analītisks nedēḷas žurnāls).

20. Pažūsis, Lionginas et. al. [b. g.]. Vertimo studiju žodynas. Vilnius: Vilniaus universitetas.

21. Purons, Viḷus. 2016. Svētais krustu mežs. Vilnius: Litera.

22. Račis, Antanas (red.). Visuotinè lietuviu enciklopedija. 1. sēj. 2001; 2. sēj. 2002; 4. sēj. 2003; 12. sēj. 2007; 25. sēj. 2014. Vilnius: Mokslo ir enciklopedijų leidybos centras. 
23. Rauhvargers, Eižens (red.). 2002. Latviešu valodas sinonīmu vārdnīca. 3. papild. un pārstr. izd. Rīga: Avots.

24. Sabaḷausks, Aḷgírds. 2014. Mēs - balti. Rīga: Latviešu valodas aǵentūra.

25. Skljarevskaja, Galina (red.). 2000. Tolkovyj slovar' russkogo jazyka konca XX v. Jazykovye izmenenija. Sankt-Peterburg: Folio-Press.

26. Skujiņa, Valentīna (red.). 2011. Lingvodidaktikas terminu skaidrojošā vārdnīca. Rīga: Latviešu valodas aǵentūra, LU Latviešu valodas institūts.

27. Skujiņa, Valentīna (red.). 2007. Valodniecības pamatterminu skaidrojošā vārdnīca. Rīga: LU Latviešu valodas institūts.

28. Šiukščienè, Virginija, Lukošiūtė, Birutè (sast.). 2016. Nepriklausomu valstybiųLietuvos ir Latvijos - kūrèjai Mintaujos gimnazijoje. Neatkarīgo valstu - Lietuvas un Latvijas - veidotāji Jelgavas gimnāzijā. Parodos knyga / Izstādes grāmata. Šiauliai: Šiaulių „Aušros“ muziejus.

29. Treija, Aldona, Dribins, Leo. 1998. Lietuvieši. Mazākumtautību vēsture Latvijā. Rīga: Zvaigzne ABC, 43-61.

30. Vēcinsš, Ēvalds. 1993. Naudas lietas. Rīga: Zvaigzne.

31. Vikipēdija (interneta enciklopēdija). Pieejams https://lv.wikipedia.org/wiki/ Lietuva

32. Vilks, Andris (red.). 1991. Enciklopēdiskā vārdnīca. 2. Rīga: Latvijas enciklopēdiju redakcija.

\section{Literatūra}

1. Ambrasas-Sasnava, Kazimieras. 1978. Vertimo mokslas. Vilnius: Mokslas.

2. Dobelienè, Regina (sast.). 1998. Lietuviu kalbos komisijos nutarimai 1977-1998. Trečiasis pataisytas ir papildytas leidimas. Vilnius: Mokslo ir enciklopedijų leidybos institutas.

3. Gudavičius, Aloyzas. 2009. Etnolingvistika (Tauta kalboje). Šiauliai: VšI Šiaulių universiteto leidykla.

4. Konsultacija. Valstybinè lietuviu kalbos komisija. Pieejams: http://www.vlkk.lt/ konsultacijos/6691-kunigaikstyste-kunigaikstija-didzioji-raide

5. Kvašīte, Regīna. 2003. „Latviešu literārās valodas vārdnīcas” leksikas aktualizācija. Vārds un tā pètī̌sanas aspekti. 7. Liepāja: LiePA, 330-340.

6. Kvašīte, Regīna. 2005. Lietuviešu tautas reālijas latviešu avotos. Vārds un tā pètǐšanas aspekti. 9. Liepāja: LiePA, 290-299.

7. Kvašytė, Regina. 2009. Tautinès realijos: pavadinimai, terminai ir jų vartojimas. Terminologija. 16. Vilnius: Lietuvių kalbos institutas, 56-67.

8. Kvašytè, Regina. 2012. Latvijos gyvenimo realijos lietuviškuose šaltiniuose. Tarp Lietuvos ir Latvijos: lingvistinès paralelès. Starp Lietuvu un Latviju: lingvistiskās paralēles. Šiauliai: Všț Šiaulių universiteto leidykla, 139-155.

9. Kvašytė, Regina, Čepaitienė, Giedrè, Župerka, Kazimieras. 2006. Istorija kaip kalbos ir raštijos stilistinio savitumo veiksnys (lietuvių ir latvių paralelès). Gretinamosios lietuviu ir latviu stilistikos klausimai. Šiauliai: VšI Šiaulių universiteto leidykla, 40-53.

10. Laugale, Velga, Šulce, Dzintra. 2012. Lielo burtu lietojums latviešu valodā: ieskats vēsturiskajā izpētē, problēmas un risinājumi. Rīga: Latviešu valodas aǵentūra. 
11. Leonavičius, Vilius. 1997. Sociologinès pastabos apie latvių ir lietuvių kalbos žodžio tauta raidą. Acta Baltica '94. Kaunas: Aesti, 38-42.

12. Mīlenbahs, Kārlis. 2009. Par svešvārdiem. Darbu izlase. Rīga: Latviešu valodas institūts, 375-394 (pirmizdev. Rakstu krājums. 13. Rīga: Rīgas Latviešu biedrības Zinību komisija, 1901, 23-46).

13. Palionis, Jonas. 1979. Lietuviu literatūrinès kalbos istorija. Vilnius: Mokslas.

14. Vilkaite, Irena, Kvašytė, Regina. 2006. Pasyvioji leksika lietuvių-latvių ir latvių-lietuvių žodynuose. Lietuviu ir latviu gretinamosios stilistikos klausimai. Lietuviešu un latviešu sastatāmās stilistikas jautājumi. Šiauliai: V̌̌̃ Šiaulių universiteto leidykla, 225-243.

\section{Summary}

Each nation characterizes with realities, reflecting certain specifics, expressed by proper nouns (personal names, place-names) and appellatives. Scholars do not reach the agreement regarding the name of the layer of the spoken lexis - the terms, used in the article is equivalent-less lexis. The words, as the realities, denoted by them, are difficult to understand to representatives of other cultures. The article examines the lexis, collected from the scientific and publicist texts on Lithuania and Lithuanians, written or translated in the Latvian language. Such equivalent-less lexis is discussed classified according to semantics: the realities of folk history (randomly classified into historicisms and actualized lexis). During the study it was established that most frequently Lithuanian names are made Latvian, i. e. Latvian endings are attached to them. The meanings of the words are commented on (in brackets or comprehensively in the text or at the footnotes). However sometimes no comments are present, which shows that the addresser (the author of the article) is of the opinion that the addressee (the potential reader) understands the lexis. It is stated that there is a lack of theoretic provisions on how such equivalent-less lexis should be rendered, which, in part, depends on the style of the text, in which the lexis is used and also, to no lesser extent - on the perception of the author. 